\title{
REGISTERING MUSLIM MARRIAGES Penghulu, Modin, and the Struggles for Influence
}

\author{
Muhammad Latif Fauzi \\ Leiden University/State Institute of Islamic Studies (IAIN) Surakarta \\ email:mublatiffauri@gmail.com
}

\section{Abstract}

This article deals with the position of penghulu and modin and examines how they struggle for influence in the context of marriage registration. Materials of this article result from my ethnography in a village in East Java in 2017. I did interviews, participant observation and document analysis and applied the "state-in-society" approach to analyse the finding. In this article, I suggest that to maintain their influence, penghulu tend not to present themselves as ulama although their identity as a religious authority is bighly important. Instead, penghulu identify themselves as the state agency by materialising their authority to provide state recognition of Muslim marriages into the resource of power. On the other hand, modin play important roles in bridging the relationship between the state and society. Modin find themselves subject to compromise between competing legal orders so that they sometimes need to produce an alternative legal norm to make their intermediary role possible. [Artikel ini mendiskusikan posisi penghulu dan modin serta melihat bagaimana mereka berjuang untuk berebut pengarub di masyarakat dalam halpencatatan perkawinan. Bahan-bahan artikel ini diperoleh dari etnografi yang saya lakukan di sebuah desa di Jawa Timur pada tabun 2017. Saya melakukan wawancara, observasi partisipatif, dan analisis dokumen serta menggunakan pendekatan "state-in-society" untuk menganalisa temuan lapangan. Saya menyimpulkan bahwa untuk mempertahank an pengarubnya, penghulu cenderung tidak menampilkan dirinya sebagai ulama meskipun identitas mereka sebagai otoritas agama tetap penting. Sebaliknya, mereka 
mengidentifikasi diri mereka sebagai agen negara dengan mentransformasi otoritas untuk memberikan pengakuan negara atas perkawinan sebagai sumber kekuasaan. Selain itu, modin memiliki peran penting dalam menjembatani bubungan negara dan masyarakat. Modin berada dalam situasi kompetisi antar norma bukum sehingga terkadang perlu untuk membuat norma bukum alternatif untuk mempertahankan posisi mereka.

Keywords: penghulu, modin, nikah bedolan, nikah kantor

\section{A. Introduction}

"Ancaman saya begini: Saya turun jabatan atau buku nikahnya saya coret. Saya tidak mau instansi pemerintah dilecehkan."

(My warning is like this: I step down or I cross out the marriage certificate. I do not want a government institution humiliated.)

Pak Yusuf, the head of a KUA office in Pasuruan

It was at the end of January 2017. I suddenly stopped my motorcycle when I passed the Sumbersari's grand mosque in Pasuruan. I looked to a green building next to the mosque. The building looked dirty, the front garden was untidy, but the entrance gates were left open. A small signboard reading 'Kantor Urusan Agama' was still hung on the fence. Leaves of a mango tree at the corner of the garden covered some parts of the signboard. I was hesitant. I then came up to a young man sitting in a warung (food stall) right across the mosque. I asked him if that building was the office of religious affairs (Kantor Urusan Agama, henceforth referred to as the KUA) ${ }^{1}$ that I intended. The young man did not rebut my assumption, but explained that since months ago the building has no longer been used. It instead has moved few hundreds of metres to the south, occupying a building that belongs to the local branch of a traditionalist Islamic organisation, Nahdlatul Ulama (NU).

On the following day, I visited the 'new' office and met with its highest official, Pak Yusuf', the kepala (head) of the KUA who at the

${ }^{1}$ It is important to remind that the KUA is a state body at the sub-district (kecamatan) level that is responsible for the administration of Muslim marriage.

2 All the names of the people here are not real. 
same time serves as the Pegawai Pencatat Nikah (PPN, the official of marriage registration). His position is socially acknowledged as penghulu or naib. Shortly, Pak Yusuf explained that they had to move because major parts of the old building do need renovation. According to him, the provincial office of religious affairs has approved the proposal for reconstruction. However, the project cannot be commenced because there is still a problem with the legal status of the land. Pak Yusuf was nevertheless less knowledgeable about the historical past of the land as he started to head that KUA since October 2014. He himself resides in an area close to Surabaya, the capital city of East Java province, that takes one hour by motorcycle to get the office. In the days where the number of marriage ceremony ${ }^{3}$ escalates, he has to overstay in the office to be able to attend marriage ceremonies held in the early morning next day. During my fieldwork, he often welcomed me to stay in the office too. I had the pleasure to receive his offer as it allowed me to not only obtain deeper information surrounding marriage registration from him, but to have extensive chats with Pak Rohmat, one of the local officers whose house is just a few dozen meters from the office. Pak Rohmat is a non-tenured employee (pegawai honorer) who has been affiliated with the KUA for more than 20 years.

Pak Rohmat explained that since it first operated in 1961, the office has rented the house next to the mosque. In the early 1990s, the government actually allocated a land near the sub-district health centre to build a new KUA office. Some local religious elites who knew about this plan reacted with harsh resistance. They argued that the KUA, which deals with Islamic affairs, was ideally located side by side with a mosque. The government finally annulled its project. Later on, with the intervention of religious leaders, the owner of the (rented) house was willing to exchange his property with the allocated land. Since then, the house has been in the government's possession. Nevertheless, the exchange was undergone unofficially. As a local villager, Pak Rohmat is assigned to cooperate with village authorities to finalise its legal status. He does not mind doing this task, arguing "because my living comes from here."

3 To avoid misunderstanding, herein marriage ceremony refers to akad nikah or ijab kabul, the stage where the woman's guardian in marriage offers the bride to the groom who then declares an acceptance. 
From this narrative, we may get an impression of how informal, religious leaders exercised their power in the (re)making of the state institution. ${ }^{4}$ The resistance against the construction of a new building is one of examples that a state institution cannot really be isolated from its social context. In this sense, Davis argues that "informality is both a mirror and a determinant of the state's formal reach". ${ }^{5}$ Moreover, it is someway clear that the KUA has been expectedly perceived not limitedly as a formal institution working on the administration of marriage. Rather, the KUA officers, let alone penghulu, KUA's functionaries dealing specifically with marriage, have been assumed to hold religious authority. This perception is based on the reason that the penghulu have the task to solemnise a marriage ceremony according to Islam or, at least, to validate whether a marriage ceremony has been in accord with Islamic rules and, therefore, is qualified for registration.

With the "state-in-society" approach, this article concerns the fact that the state agency like KUA is unlikely detached from social forces it engages. ${ }^{6}$ Klinken and Barker have emphasised "the study of the state in relation to the broader social context in which it is embedded". 7 Considering this, I would like to draw our attention to a wider debate about state in society. This article focuses on the ways penghulu negotiate their authority in a society where the influence of informal religious authorities is dominant. This article elucidates how the KUA and its officials at the subdistrict level shape and implement rules on marriage registration and analyses how they interact with different actors in the society.

On the basis of everyday practice of the KUA in my research field, I suggest that the KUA officers have the demands to negotiate its norms

4 Adam White, "Introduction: A State-in-Society Agenda", in The Everyday Life of the State: A State-In-Society Approach, ed. by Adam White (Seattle: University of Washington Press, 2013), pp. 1-12.

5 D.E. Davis, "Informality and State Theory: Some Concluding Remarks", Current Sociology, vol. 65, no. 2 (2017), p. 317.

${ }^{6}$ Christian Lund, "Rule and Rupture: State Formation through the Production of Property and Citizenship", Development and Change, vol. 47, no. 6 (2016), p. 1200.

${ }^{7}$ Gerry van Klinken and Joshua Barker, "Introduction: State in Society in Indonesia", in State of Authority: The State in Society in Indonesia, ed. by Gerry van Klinken and Joshua Barker (Ithaca, NY: Cornell University, 2009), p. 5. 
and authority with the variety of contexts. The KUA officers found it important to enhance good relationship with religious leaders and local elites in order to maintain stability. The officers, like Pak Rohmat who is a local villager, apparently play important roles in bridging their relations. Moreover, on par with the principles of "dual validity" of marriage, between the legal obligation of marriage registration and the religious nature of marriage ceremony, the flexibility of KUA officials of interpret and implement the rules determines the success of marriage registration.

The uneasy relationship between religious and administrative aspects of marriage leaves penghulu with a dilemma. This dilemma is actually not new if we trace back to the history of penghulu since the colonial era. It has been argued how state-promoted penghulu ware at the crossroad between the interests of Muslim leaders and the colonial government. ${ }^{8}$ Penghulu were sadly stereotyped by religious elites with inadequate knowledge about Islam. ${ }^{9}$ In the contemporary realm, Nurlaelawati has remarked that KUA officials, including the penghulu, cooperate with ulama and tend to position themselves as ulama than as state officials. In terms of divorce, she found that penghulu has played roles as an intermediary between ulama and religious courts. More interesting is that, as she suggested, in particular areas, the KUA officials have an ambivalent position towards the judicial divorce in a way that they proceeded marriage registration of a married couple who claimed having been in divorce but failed to present a divorce certificate. ${ }^{10}$

Despite these available scholarly works, this chapter asks this fundamental question: In what ways does penghulu maintain their authority? This resonates with other questions, such as: What language do they use to struggle for power in society? How do people deal with them? In what ways do modin play roles? What can we theoretically explain from the everyday interaction between people, modin and penghulu? By proposing these questions, this article seeks to scrutinise the (political)

8 Muhamad Hisyam, Caught between Three Fires: The Javanese Pangulu under the Dutch Colonial Administration, 1882-1942 (Jakarta: INIS, 2001).

9 Ibid.

${ }^{10}$ Euis Nurlaelawati, Modernization, Tradition and Identity: the Kompilasi Hukum Islam and Legal Practice in the Indonesian Religious Courts (Amsterdam: Amsterdam University Press, 2010), p. 189. 
position of penghulu, and the KUA officers at large, in society. It then elucidates how penghulu seek for influence in navigating the practice of marriage in accordance with the state laws.

This article includes six sections. Following this introduction, I briefly elaborate a foundational framework on which this article stands. The next section seeks to demonstrate the social context in which the state is supposed to exercise its legal authority. From this point, I am going to address the image of the state to begin the core discussion of this article. Here, I look at different attitudes that interact within the institution. Later on, I expand the discussion of the image by an analysis about the recent trend of marriage registration. The sixth section examines the interaction between penghulu and social forces in the making of marriage practice.

\section{B. Marriage Registration and the State-in-Society Approach}

Pak Yusuf's words that began this chapter necessarily indicates that the state's legal authority over marriage is never sterile from challenges. Marriage has been, and is still, subject to competing authorities. ${ }^{11}$ To figure out the complicated position of state officials like Pak Yusuf in society and its relation with informal authorities, ${ }^{12}$ this chapter applies the conceptual framework of 'state-in-society' that has been subject to debate in the last decades. Among others, Joel Migdal is one of the leading scholars on the subject. His book published in 2001 "State in Society" 13 has been fundamental in providing insightful viewpoints to deal with the inquiry of the making and the remaking of the state in the face of social realities. State-in-society approach is at large developed as a response to the fact that our today's modern world is shaped by the authority of the state with the force of its formal rules. However, how these rules in practice are determined by "those who are supposed to

11 Elizabeth S. Scott, "Social Norms and the Legal Regulation of Marriage", Virginia Law Review, vol. 86, no. 8 (2000), p. 1903.

12 Recent study of the state and society has considered informality an analytical point of departure for theorizing governance, citizenship, and social order. Davis, "Informality and State Theory: Some Concluding Remarks".

13 Joel S. Migdal, State in Society: Studying How States and Societies Transform and Constitute One Another (Cambridge: Cambridge University Press, 2001). 
enforce them" and by "those who are supposed to obey them". ${ }^{14}$ This situation inescapably gives rise to a wide range of competing authorities and discourses. Given this, it seems unlikely to avoid the necessity to look at the compound relationship between state authority and everyday social actors, comprehending their multiple narratives and political activities as the mutual process of constituting one another. The relationship between them is accordingly perceived as a dialectical process.

This perspective leads to a new, yet distinctive definition of state. It revisits one proposed by earlier scholars like Weber who conceptualised state on the basis of its institutional nature as powerful organisation that allows it to be a resource to coercion. ${ }^{15}$ This old understanding of the state materialises in Weber's commonly mentioned definition that "a state is a human community that (successfully) claims the monopoly of the legitimate use of physical force within a given territory". ${ }^{16}$ At the core of this definition clearly lies the notion of domination by the means of physical force in the state's territory. Migdal sought to perceive domination as neither centred nor single, exclusively occupied by a formal organisation. Instead, he comes up with the idea of "society's multiple arenas of domination and opposition". ${ }^{17} \mathrm{He}$ further suggests that state is a power that "embodies an ongoing dynamic, a changing set of aims" as the consequence of social forces engaged. ${ }^{18}$

In the study of Islamic law and society, this state-in-society approach necessarily brings me back to a number of works which have suggested the so-called cultural shape of state activity. One of which is the seminal work by Rosen on the practices of the qadi in the context of Islamic law and Moroccan social and cultural life. ${ }^{19}$ On the basis of the local sharia court records (sijill) in the town of Sefrou, Morocco, he

14 White, "Introduction. A State-in-Society Agenda", p. 3.

15 Migdal, State in Society: Studying How States and Societies Transform and Constitute One Another, p. 111.

16 Max Weber, "Politics as a Vocation", in From Max Weber: essays in sociology, ed. by Hans H. Gerth and C. Wright Mills (New York: Oxford University Press, 1946), p. 78.

17 Migdal, State in Society: Studying How States and Societies Transform and Constitute One Another, p. 99.

18 Ibid., p. 112.

19 Lawrence Rosen, The Anthropology of Justice: Law as Culture in Islamic Society (Cambridge: Cambridge University Press, 1989). 
found that the oaths and the use of professional witness are not truly based on the exact reality, but a matter of the qadi's construction as the result of a process of negotiation. This all is to establish judicial facts that make it possible for the qadi to draw decisions.

Migdal offers two-aspect definition of the state. He states: "The state is a field of power marked by the use and threat of violence and shaped by (1) the image of a coherent, controlling organization in a territory, which is a representation of the people bounded by that territory, and (2) the actual practices of its multiple parts. ${ }^{20}$ The first aspect, the state's image, assumes the state as a dominant and autonomous entity that controls the direction of the given society. This also relates to how the state has become an integral part of everyday social relations to explain why it continues to exercise a certain form of authority. ${ }^{21}$ The second aspect, the practice, connects with the ways the state's image is reinforced or weakened by the state officials and societal agencies. Simply, it focuses on the variety of practices that influence the sharp demarcation between the state and the society. ${ }^{22}$ In this respect, we can see how state authority is negotiated by different actors.

By following this framework, I perceive Muslim marriage registration as a political activity that involves the interaction between the state agent and everyday societal agency. First, I look at the development of registered marriage. I then examine the practices of penghulu and its KUA in addition to the image it portrays. For the image, I analyse internal dynamics within the KUA to understand the ways penghulu maintains the position of the KUA. For the practice, my attention will focus on the recent trend in the practices of marriage ceremony and marriage registration that have provided the ground where different authorities continue to contest.

\section{Building an Internal Synergy, Maintaining the Power}

In this section, I wish to explain how the KUA looks like so as

20 Migdal, State in Society: Studying How States and Societies Transform and Constitute One Another, pp. 15-6.

21 White, "Introduction. A State-in-Society Agenda", p. 13.

22 Migdal, State in Society: Studying How States and Societies Transform and Constitute One Another, p. 20. 
to reveal how people perceive it. For this end, this section analyses the attitudes and the interaction between functionaries in the KUA's everyday life. Positions in the KUA can be simply divided into three categories, namely the head (kepala), marriage officials (penghulu), and administration officers. In KUA Sumbersari, these positions are run by four persons: two are civil servant, while the other two is non-tenured local officers. The office itself occupies a two-floor building. The ground floor involves a main-long room and four small rooms. The main room includes two desks, in the front and in the back, separated by an old sofa-set in the middle.

The first civil servant is Pak Zaki. He occupies the front desk that functions as a registration counter. Pak Zaki was as a teacher in a state Islamic school in the town Bangil. In 2014, he decided to leave the school to become an officer of the KUA. "I want to be more relax with this new position", Pak Zaki said. Pak Zaki is responsible for managing the buku register (registration book). This book contains personal details of the brides and the grooms, date of registration, the proposed date of marriage ceremony, the bride's guardian, and the place of marriage ceremony. He might be true that his new occupation is less hectic than the previous job. However, in regards to marriage administration process, Pak Zaki's desk is at the heart of all the procedures. Practically he is the one who verifies the accuracy of the data (name, age, and the guardian of the brides).

In addition to Pak Zaki is Pak Yusuf who occupies the back desk. Pak Yusuf started his career as a civil servant under the office of religious affairs of Pasuruan in 1985. Since then he has always been working as an officer in KUA offices, moving from one office to another across the region. He was not trained in Islamic university nor graduated from pesantren. Rather, he went to vocational high school (Sekolah Menengah Kejuruan) in the 1970s and later on pursued a bachelor degree in economics with the degree of Sarjana Ekonomi (SE). With the possession of the bachelor degree, he was qualified to be promoted as a structural official (pejabat struktural), i.e. the kepala of KUA. In the past, it was possible that an administration officer got promoted as the kepala as long as has met the required conditions. Pak Yusuf made it in the end of 2004. At this position, Pak Yusuf also serves as a marriage registrar (PPN, Pegawai 


\section{Pencatat Nikah).}

In the past, Kepala of KUA was not always a penghulu although penghulu could, at the same time, have a structural position (jabatan struktural) as the kepala of KUA. In Pak Yusuf's case, he is the kepala but is not a penghulu. Nevertheless, because the office does not have its own penghulu, he automatically undergoes the function as penghulu. This kind of situation sometimes leads to problems if he is not well skilled with religious competencies as expected by the society. Regardless, the government has changed the regulation concerning the kepala of KUA. Currently, the kepala of KUA must be a penghulu.

The fact that Pak Yusuf has to act as penghulu became a crucial issue in Sumbersari. Local people problematised his educational background as he never went to an Islamic school. Pak Yusuf is not adequately trained in Arabic. It is worth to note that particular societies, like in Sumbersari, strictly demand activities in marriage ceremony, including the marriage sermon (khutbah nikab), the offer (ijab), and the acceptance (kabul), done in Arabic. They believe that the use of Arabic makes the marriage ceremony more blessed. This definitely requires penghulu's good skill of recitation of Quranic texts or proficiency (fasib) in reciting prayers in Arabic.

Some wooden-framed posters are hung on the wall nearby Pak Zaki. At the top, a big poster pertains to the regulation concerning the mechanism of marriage registration fee which stresses the difference between nikah di KUA (marriage in the KUA) and nikah di luar KUA (marriage outside the KUA). Beneath it, a poster contains a hadith on marriage guardian and witnesses in marriage contract. The hadith says $l \bar{a}$ nikeạha illa biwaliyyin wa shähiday 'adlin (no marriage except with a guardian and two non-discredited witnesses). It also contains a description of the order of the guardian which only comes from paternal side. If the bride's father is absent, there are twenty guardians that can orderly replace him, ranging from grandfather to oldest son of great paternal uncle.

A couple of meters from Pak Zaki is a room where two nontenured officers execute their work. Their position is commonly called sukwan, which comes from the word sukarelawan (voluntary). They are local natives, Pak Rohmat and Pak Hamid. First, Pak Rohmat, as abovementioned, has the main task of organising marriage documents. As 
his house is close by the office, he is also assigned to handle the operation of the KUA. Every morning, before the office hours, he opens the door and cleans the floor. In the evening, he comes back to the office to make sure that everything is safe. Pak Rohmat is also responsible for recording the personal details of the marital couples in the buku bantu register (backup registration book). The difference of this book from buku register that is kept by Pak Zaki lies in the column that mentions the number of marriage book (buku nikah) or the copy of marriage certificate (kutipan akta nikah) that is to be given to the married couples. Pak Rohmat also takes charge of writing their details in the buku nikah. Each couple receives a buku nikah. One with green-cover is for the wife (buku nikah istri), while the red-brick cover is for the husband (buku nikah suami). Second, Pak Hamid works on managing electronic data. Since 2013, the data of the married couples have been managed electronically. The system is called SIMKAH (Sistem Informasi Manajemen Nikah).

Pak Rohmat and Pak Hamid are from families of religiouslyrespected circles who have played considerable roles in the development of the institution. In 1992, after finishing his secondary high school, Pak Rohmat replaced the position of his big brother who just got promoted as a civil servant. Currently, his brother is serving as a penghulu in another sub-district. When taking over his brother's position, Pak Rohmat had the same wishes, to be a civil servant too. Therefore, some years ago he took a bachelor degree in Islamic education that he meant to accelerate the promotion. However, up to now, he remains not promoted. Meanwhile, Pak Hamid is a local villager who is a graduate of a prominent pesantren in the town which does not adopt secular education. Local people regard him more as an Islamic teacher (ustady). He leads an informal Islamic school (madrasah diniyah) in a pesantren that belongs to his uncle who is of the top leaders of the local branch of NU. Due to this activity, he does not work full day in the KUA. Moreover, it is his uncle that has the authority to permit the use of the building for the temporary operation of the KUA. In addition, his father was reported as one who made the land barter transaction in the past possible.

From their everyday performance, we can easily identify the difference between the civil servants and the non-tenure officers. Their performance necessarily demonstrates the formal and the semi-formal 
position of them. Pak Zaki and Pak Yusuf wear a more formal dress, white long-sleeve shirt on certain days, with an official pin attached on their left chest. In addition, Pak Yusuf always wears Islamic-typical cap (kopyah) covering his head. It seems that the kopyah says something about his state-sanctioned authority on Islamic matters. At the contrary, Pak Rohmat and Pak Hamid dress more informally.

Although Pak Rohmat and Pak Hamid are non-permanent workers, their position is definitely of high significance. First, as already mentioned, their family is genealogically linked with religious elites. Second, as the locals, they are emotionally close to modin. Modin is an informal marriage functionary, was seemingly formal, at the village level whose authority derives from the appointment made by the village headman (kepala desa). The majority of them is graduates of pesantren education. As part of tradition, marriage ceremony, particularly the couple's first marriage, in the area always falls under the care of modin. At its position, modin not only organise administrative papers for registration, but also arrange the whole process of marriage ceremony. Third, Pak Yusuf tends to assign one of the local officers to represent him, once he cannot make it, in monthly informal meetings that involve modin and village officials.

Meanwhile, taking care of the registration desk, the civil servant Pak Zaki feels bound with the state regulation. Pak Zaki argues that he just implements the procedure as is written. Quite often he receives complains from modin that he is considered terlalu ketat (too rigorous) and mempersulit (complicating). This usually happens when Pak Zaki demands the couples to come for rafak (document verification), but the modin is hesitant to make it for several reasons. One of which could be that one of the couples still stays in pesantren or work out of the town. The case can also be that the couples did not yet sign the marriage consent form. In this situation, modin usually comes to Pak Rohmat to discuss the situation with an expectation that he helps to convince Pak Zaki that everything will go fine. Pak Zaki's concern is "If an official from the district office of religious affairs performs an audit and he finds something odd; it is none of your (modin's) responsibility. Instead, we get blamed." Therefore, in certain occasions the PPN, Pak Yusuf, has to intervene the tension, stating. "Up to you, modin. If you do not follow our rules, please do not work with us!"

From the above explanation, we see the entanglement of issues, 
ranging from social forces behind the local officers and the manoeuvres of modin, that shades everyday practice of the KUA. Pak Yusuf is aware of this situation that he needs to manage his authority, exercising the power of domination, very carefully. As the PPN, he is a representative of the state, but as a penghulu, he is assumed to represent religion. Pak Yusuf let the local officers play roles in bridging the communication between the KUA and the local people. Meanwhile, Pak Zaki tends to place himself as the guardian of the state rules. These attitudes altogether have been important for co-shaping the everyday image of the KUA as an institution dealing with Islamic affairs on the one hand and as a state body in charge of marital administration on the other.

\section{Registering Marriages and Remarriages}

As far as marriage practice throughout East Javanese villages are concerned, when the date of marriage ceremony is agreed on by the two families concerned, the girl's father comes to a modin. He asks modin's help to arrange the marriage ceremony. Disclaimer, however, should be made. People always go to modin in the case of first marriage where either the bride or the groom, or both of them, is unmarried before. If it is not a first marriage for one of the couples, there is no guarantee that modin is used. The father-modin interaction marks the initial process of the implementation of the state laws on marriage. In Sumbersari setting, I observed a conversation between a father and a modin as the following:

Father : Pak Haji, I am going to marry my daughter. How much to buy (get) a marriage certificate?

Modin : Praise be to Allah, your daughter has found her future husband. Wish her a blessed relationship in this world and in the hereafter. Marriage certificate is not buying, but has to do with marriage registration that requires some conditions. First, marriageable ages: for women 16 years, and for men 19 years. Second, you have to hand in a family card, an identity card, and a school diploma.

Father : Yes, they all are ready.

Modin : Are you going to handle the registration yourself or ask me to make it? 
Father : I want you handle it, Pak Modin, including the marriage ceremony.

Modin : If you wish so, the cost is this (certain amount), covering the organising of all the documents, transport cost, and marriage ceremony.

The above conversation clearly shows that the villagers generally perceive marriage registration as "buying a marriage certificate". They argue because they need to spend a certain amount of money to attain it. The modin usually tell them that it is not buying a letter, but registering a marriage. Not only in marriage registration, this kind of perception also applies to judicial divorce. The locals use the phrase of melleh talak ka hakim (buying divorce from religious judges). Some people name it with melleh kartu koning (buying a yellow card) because the divorce certificate for a wife has yellow ornaments on it.

Despite the local perception of marriage registration as buying a marriage certificate, if we look at the figures of registered marriage, it appears that marriage registration has increasingly become an important part of local marriage practice. I talked with many of modin and they generally confirmed that marriage registration has become people's need. One of them said: "It has changed now. Nearly all marriages are registered in the KUA." With 61,650 Muslim population, Sumbersari sub-district has around 500-550 registered marriages a year. In the Pasuruan regency with Muslim population of 1,604,325 in 2015, the number of marriages is around 14,150 a year. The highest number of marriages in the most populated sub-district, Gempol, with 199,272 of Muslim population is 1,308 per year. The lowest number, amounting to 99 marriages a year, belongs to the Tosari sub-district, where Muslim population is 5,625. ${ }^{23}$

My materials from the local KUA record show that there was an incredible increase in marriage in 2010 compared to previous years. In 2008, registered marriage was around 485 and it elevated to 642 in 2010. I, unfortunately, did not have enough materials to explain this escalation. However, if allowed to make speculations, on the basis of information that I collected from modin, it was driven by different factors. First, the

23 BPS Kab. Pasuruan, Kabupaten Pasuruan dalam Angka 2016 (Pasuruan: BPS Kab. Pasuruan, 2017), p. 232. 
ever-married couples tend to register their remarriage. Second, people are more aware that many incentives such as government subsidies or access to bank loan are more welcome with the possession of marriage certificate. Third, both parents find it important to list their names on their child's birth certificate. What follows is the figure of registered marriage since the 1960s until today.

Since 2015 there has been a tendency of the decline in marriage registration. When I consulted this with the officers of the KUA, they argued that the decline is neither caused by the decrease in marriage nor the rise of unregistered marriage. Social mobility seems to be the major factor contributing to this change. Unlike in the past that marriages generally involved between local peoples, now young generations have an ample opportunity for establishing cross-cultural families. This indication can be seen from the introductory letter (surat pengantar) issued by the local KUA for a groom to register his marriage in the KUA with which the bride is affiliated.

People's attitude towards the importance of marriage registration not only applies to first marriage, but also remarriage. The number of remarriages, where one of the couples or both is janda (ever-married women) and duda (ever-married men), constitutes nearly one-fourth of the whole marriage. ${ }^{24}$ In the year 2015 , there were 124 remarriages out of 553 marriages or $22.42 \%$. Meanwhile, in the year 2016, there were 122 remarriages out of 532 marriages or $22.93 \%$. This figure also suggests another aspect that there has been an increase in people's awareness to seek for judicial divorce from religious court. Based on the records from Islamic court in 2015, the number of divorce of marriages that were registered in KUA Sumbersari was 104. 23 were divorces initiated by husbands (cerai talak) while the rest 81 were requested by wives (cerai gugat). Here, the ratio of divorce is $18.9 \%$ compared to the number of marriages of the same year. From this figure, I assume that both KUA and religious court have increasingly shaped people attitudes in coping with marital matters. This finding corroborates earlier studies that shed light on the blast of divorce cases in Indonesian religious courts over

24 The KUA administration and the civil registration in Indonesia differentiate between janda mati (widow) and janda cerai (divorced woman) as well as duda mati (widower) and duda cerai (divorced man). 
the last decade. ${ }^{25}$.

\section{E. Akad Dua Kali (twofold marriage ceremonies), modin and penghulu's domination}

People's changing attitude towards marriage registration, as shown in the previous section, underscores optimism about the effective functioning of the state as a body wielding legal authority. Does this mean that people are now more inclined to dispense their religious affairs to the state agent? If so, to what extent does it affect the roles of traditional leaders? With reference to the law no. 22/1946 on registration of Muslim marriage, divorce, and reconciliation, article 6 of the Compilation of Islamic Law states that a marriage ceremony must be concluded before and under the supervision of a marriage registrar (PPN). However, back to the statement at the beginning of this article, it is obvious that Pak Yusuf sought to proclaim its state-bestowed power of legalisation of Muslim marriage. He even played with threats to emphasise its authority. This situation leads me to an inquiry of what has actually happened to state-society relationship behind marriage registration.

Somewhere in May 2017, a family whose daughter would be going to wed held a walimah in a Pasuruan village. Walimab is a religious congregation that aims to make a marriage ceremony (akad nikah) publicly announced. It is usually held in the morning, inviting relatives, neighbours and respectable figures of the village. The groom and a few of his family members also attend. The programme starts with the recitation of mawlid (prayers for the Prophet) and prayers, most of the time ended with akad nikah ceremony. Two weeks before, when the bride's father was visiting Haji Misbah, a modin of the village, to arrange the marriage ceremony, he decided to register it as nikah kantor, marriage in the KUA office. Haji Misbah asked the father about who would serve as the munakkih, stating the following:

"I told the father that the obligation of marrying a woman returns to the wali. It is much better, if the wali can make it himself. However, he can

25 Euis Nurlaelawati, "Muslim Women in Indonesian Religious Courts: Reform, Strategies, and Pronouncement of Divorce”, Islamic Law \& Society. 2013, vol. 20, no. 3 (2013), pp. 242-71; Mohamad Abdun Nasir, "Islamic Law and Paradox of Domination and Resistance”, Asian Journal of Social Science, vol. 44, nos. 1-2 (2016), pp. 78-103. 
delegate it to another figure as he favours. It is though common that the wali gives it to the modin. However, the wali remains obliged to be present in the marriage ceremony."

Shortly, the walimah was held on the same day as the akad nikah scheduled by the KUA. In the meantime, the father was persuaded by his family to include the akad nikah in the walimah as is commonly practised. It was said: "mumpung Gus Akib rawuh, dinikahno sekalian ae" (while Gus Akib is present, better to marry them now). Gus Akib is a prominent religious leader with whom the bride's family consult about Islam and other matters. Living within the pesantren tradition, the locals still hold the belief in the concept of barakah (blessing), a quality which is reflected through people who perform good religious acts. ${ }^{26}$ They idealise a blessed marriage ceremony through the intermediary of Gus Akib. The father thus brought up the situation to Haji Misbah, the modin, who was among the guests in the walimah. Haji Misbah had no objection, allowing the akad nikah to take place, but insisted him to conclude a successive akad nikab in the KUA a few hours afterwards. This practice led to so-called akad dua kali.

A religious leader like Gus Akib who was willing to marry them in a religious manner is probably exceptional. Gus Akib is a village-level religious leader. Some religious leaders with high reputation usually deny to marry the couples, unless the pengbulu is present. ${ }^{27}$ They suggest the family to held the ceremony directly in the KUA because they do not invite the penghulu to come to home. These religious leaders understand the consequence of marriage with no registration. They tend to support the authority of the penghulu and the KUA and perceive both marriage ceremony and the registration as a one inseparable process.

It goes without saying, this kind of akad dua kali practice constituted the context why Pak Yusuf expressed such a harsh statement. It was said

26 In the Sufism doctrine, one can receive God's blessing through the intermediary of a holy man such as a saint or the murshid. Within the pesantren tradition, students are supposed to respect their teacher not only in the classroom but also in all aspects of life. The failure to give respect may cause the loss of barakah of the teacher. See Martin van Bruinessen, Tarekat Naqsyabandiyah di Indonesia (Bandung: Mizan, 1992), p. 215; Zamakhsyari Dhofier, The Pesantren Tradition: The Role of the Kyai in the Maintenance of Traditional Islam in Java (Tempe: Arizona State University, 1999), pp. 61-2.

27 This is according to Pak Syukron, a modin in Sumbersari. 
in response to the phenomenon of akad dua kali that has occurred during the last years. This practice emerges as a consequence of the new policy drawn by the central government in 2014 that has set a stricter boundary between marriage in the office (nikah kantor) and marriage outside the office (publicly known as nikah bedolan). ${ }^{28}$ It is worth to note that the basic principle is that a marriage ceremony is held in the KUA office. This is according to article 21 point (1) of the regulation of Muslim marriage registration. ${ }^{29}$ Interestingly, point (2) regulates that considering the proposal of the brides and with the PPN's agreement, a marriage can be held outside the KUA office. Now, the difference between nikah in the KUA and outside the KUA becomes more obvious due to the application of the multiple tariffs. Those who perform nikah kantor are charged Rp. 0. Meanwhile, the couples' family have to pay more, Rp. 600,000 (more or less 40 US dollars), if they wish to conclude a marriage ceremony outside the office or out of working hours. Before 2014, there was no difference between the two.

The differentiation of the tariffs in fact gives rise to the practice of akad dua kali. In a simple way, akad dua kali is a marriage ceremony that is originally proposed to be nikah kantor, but in practice involves both nikah bedolan and nikah kantor. Nikah bedolan is done traditionally, without the attendance of a penghulu, while nikah kantor is done in the KUA solely for the sake of state recognition. They are most of the time performed on the same day. The issue seems to revolve around money. However, in regards the aforementioned story, it has to do with more fundamental aspects such as the ideal of marriage ceremony in the eyes of local people. This section demonstrates how penghulu negotiates its authority within the pressure of numerous forces: the state, local tradition, and his own interest.

By the new regulation, it appears that the state seeks to increase its intervention in marriage. Due to the alleged issue of eradicating

28 Peraturan Pemerintah (Government Regulation) No. 48 Tahun 2014 tentang Perubahan atas Peraturan Pemerintah Nomor 47 Tahun 2004 tentang Tarif atas Jenis Penerimaan Negara Bukan Pajak yang Berlaku pada Departemen Agama (on the Revision of the Government Regulation No. 47/2004 on the non-tax revenue of the Department of Religious Affairs).

29 Peraturan Menteri Agama (The regulation of the Minister of Religious Affairs) No. 11/2007 on Pencatatan Nikah (marriage registration). 
gratification amongst penghulu, the campaign of nikab kantor has actually started some years before. Considering this development, the central government has done significant efforts to enhance the KUA office to be an 'ideal house' for marriage ceremony, called balai nikah (marriage house). In Sumbersari setting, the second floor of the office is an open hall that functions as the balai nikah where marriage ceremonies are concluded. The existence of balai nikab becomes increasingly important, irrespective of the fact that the majority of them still has less adequate facilities. For this reason, the central government has spent considerable amount of budget to renovate hundreds of KUA building throughout Indonesia. ${ }^{30}$

Certainly, the differentiation between nikah kantor and nikah bedolan was not issue in the past because there was no difference of the tariffs. My observation in Sumbersari shows that about $95 \%$ of marriage ceremonies prior to 2014 were undertaken outside the office. In 2017, the condition has absolutely change where the rate of nikah bedolan was $24 \%$ of 531 marriages. This pattern is not typical to Pasuruan villages, but also in everywhere. Let us have a look at the detailed figures in a KUA within the urban community in the town of Jember, East Java. ${ }^{31}$ In 2013, the ratio of nikah bedolan was $92 \%$ of the whole marriage (730 of 799), and it declined significantly in the two years after. In 2014, nikah bedolan was 598 of $792(76 \%)$, while in 2015 was 439 of $746(59 \%)$. It climbed a little bit in $2016(64 \%)$ and in 2017 (76\%), although the rise is still far below that of 2013 .

Similar to Jember, in Yogyakarta, the difference of the tariffs does not influence much. The rate of nikah bedolan remains high, approximately $85 \%$. A number of factors underlines this situation. First, people in Yogyakarta generally perceive the state penghulu as a religious official with adequate knowledge of Islam. So, they just submit all marriage matters to pengbulu. In many cases, it is pengbulu who leads the marriage ceremony and serves as munakkih. Second, the amount of nikah bedolan is not significant for them. Third, they tend to held nikah bedolan because

30 Kemenag, "Tiga Tahun Jokowi-JK: Kemenag Pemrakarsa Dan Investor Terbesar SBSN,” accessed May 7, 2018, https://kemenag.go.id/berita/read/505984/ tiga-tahun-jokowi-jk--kemenag-pemrakarsa-dan-investor-terbesar-sbsn.

31 This data is calculated from the SIMKAH record that I obtained from a colleague of mine who is a penghulu in that KUA. 
they want to invite their relatives, neighbours and colleagues to witness the ceremony. Fourth, for social recognition, some families held the marriage ceremony in prestigious places, such as in hotels or halls. For this interest, no reason not to invite penghulu. However, a small number of them choose to have nikah kantor. The reason is usually because they do not want complexities and avoid being busy. ${ }^{32}$

The variety of these practices, as I claimed before, without doubt has to do with the implementation of multiple tariffs. Haji Misbah argued: "the problem is that the difference is very big, R. 600,000 for villagers is a significant amount." Throughout the years 2004-2013, marriage administration costed Rp. 30,000. With the assistance of modin, people in fact spent around Rp. 350,000; around one-third of the amount for the KUA nonetheless. As shown in the above story, the brides' families generally preferred the akad nikah held within walimah for at least two benefits: the participation of villagers and the involvement of honoured religious leader. Marriage ceremony has been a fundamental arena where religious leaders exercise their authority.

As is commonly found in Muslim community across the nation, marriage ceremony is both religious and social activities. ${ }^{33}$ Muslim scholars in general argue that Islamic marriage is an embodiment of the elements of civil contract, spiritual practice and worship of the divine. ${ }^{34}$ It further means that Islamic marriage is not merely a matter that comes under the category of mu'amalab (civil contract), i.e. pronouncing a contract of ijab (offer) made by the woman's guardian (wali), qabul (acceptance) by the man, and the payment of dower (mahr). It is nevertheless a contract that has the dimension of ibadah (ritual acts) in which normative and traditional elements of religion are engaged..$^{35}$ Therefore, in social practice,

32 This is summarized from my interview with Pak Nasrudin, a penghulu in Yogyakarta, August 2019.

33 Ziba Mir-Hosseini, Marriage on Trial: Islamic Family Law in Iran and Morocco (London and New York: I.B. Tauris, 2000).

34 Joel A. Nichols, "Religion, Family Law, and Competing Norms", in Negotiating State and Non-State Law: The Challenge of Global and Local Legal Pluralism, ed. by Michael A. Helfand (Cambridge: Cambridge University Press, 2015), p. 197.

35 Ziba Mir-Hosseini, "Marriage", Encyclopedia of Islam and the Muslim World (New York: Macmillan, 2004). 
we see the interweaving of marriage ceremony with religious rituals, ${ }^{36}$ such as the recitation of verses of the Quran, sholawat (prayers for blessings on the Prophet), and tablil (prayers for the ancestors). I witnessed the similar rituals in Pasuruan villages. Even for certain communities there, particular days, like Friday Pon ${ }^{37}$ are believed sacred for a marriage ceremony.

I discussed this issue with a local religious leader, Kyai Karim. He argued that it is understandable that people tend to conclude a marriage ceremony at home. His concern revolved around the religious capacity of penghulu because religious leaders in general assume penghulu to perform as ulama. In fact, Pak Yusuf has never been trained in an Islamic institution. Kyai Karim criticised the government for taking it too easy in promoting its functionary to be a penghulu. Another aspect he stressed was that facilities in the KUA are not yet appropriate (pantas) for conducting a marriage ceremony. He argued both the bride and the groom must be "respected" (dimulyakan). On certain busy days, they have to queue like people taking raskin (beras miskin, rice for the poor). Kyai Karim further said:

"I heard public rumours that the penghulu is less competent. His skill of reciting ayat (Quranic verses) and doa (prayers) is someway annoying. People are certainly hesitant to involving him in marriage ceremony. Marriage is a sacred ceremony. It is an ibadah. Like sholat, if you do not recite surah Al-Fatihah, the main element in sholat, in a proper way, your sholat is not accepted."

This kind of perspective has been a common understanding of the villagers through times. As such, they perceive akad nikah as a crucial stage in marriage practice that needs careful handling. There is a feeling of firmed (yakin) about the religious validity (keabsahan) of akad nikah if it is guided by a prominent religious leader, in addition to the issue of obtaining barokah. In nikah bedolan, people mostly ask their respected kyai to lead the marriage ceremony, while in nikah kantor, they tend to delegate the rights to marriage guardianship to modin, not penghulu. This situation also explains why modin still survive because their roles can meet religious-cum-administrative interests. Occasionally, parents bring

36 Ann Black, Hossein Esmaeili, and Nadirsyah Hosen, Modern Perspectives on Islamic Law (Cheltenham: Edward Elgar Publishing, 2013), p. 114.

37 Pon is one of the five-day pasaran (marketplace) cycle in the Javanese calendar. 
their preferred munak kih ${ }^{38}$ to the office. In a peculiar condition, it is said that there were families who had to perform a repetitioned akad nikah at home because they felt doubt about the validity of the earlier akad nikah at office. In this sense, akad dua kali can be both ways, home then office and vice versa.

The phenomenon of akad dua kali demonstrates ambivalence of the state's attempt to control marriage. For Pak Yusuf who is at the basic frontier of the Muslim marriage registration, this development is indeed a drawback. My informant, a high official at district office of religious affairs, did not disregard that people in Pasuruan villages still perform great dependence (ketergantungan) on kyai that gives rise to the uneven relationship between state penghulu and religious leaders. ${ }^{39}$ Pak Yusuf is aware that what has challenged him is the force of informal religious authority. This situation leads him to speak on behalf of the state, rather than to perceive himself as religious authority. In so doing, he exploits the authority of giving state recognition of religious marriage as the means to negotiate. Here is his statement:

"I do not like that they are first married at home, and later conclude another marriage ceremony in the KUA. Usually I ask the witness whether or not they are already married. If so, I say: If you want a marriage certificate, just ask to your kyai!"

Not only the penghulu, Haji Misbah who serves as the intermediary between the state and people found a dilemma too. He apparently proposed the notion of what he called ta'kidun nikah. I failed to find out the origin of this concept. Literally speaking, the first word " $t a$ 'kid" is associated with the Arabic word tawkid, meaning endorsing or ratifying. ${ }^{40}$ Ta'kidun nikah can be meant as authenticating a marriage (pengukuban pernikaban). With this concept, Haji Misbah expects that akad nikab in the KUA just aims to provide a state authentication over the foregoing religious marriage. Interestingly, he also applied this concept in another

38 Munakkih is a person to whom the marriage guardian delegates his authority to marry his daughter.

39 Interview with Pak Usman, the head of the section of Islamic guidance of the Pasuruan office of religious affairs, February 2017.

40 Elsaid M. Badawi and Muhammad Abdel Haleem, 's/و w w-k-d', ArabicEnglish Dictionary of Qur'anic Usage, Leiden edition (Brill, 2008), p. 1044. 
context, that is underage marriage. If the bride has not yet reached a marriageable age according the law, the couples are first married in a religious way. Later when the woman's age is already legally qualified for marriage registration their marriage is registered to the KUA.

Additionally, the issue of akad dua kali came up in a series of meetings between the KUA and modin. Pak Yusuf harshly cautioned the modin to prevent this marriage, saying "Don't ever marry them at home!". However, in addition to the issue of competing authorities, there has been another aspect that becomes his, and other penghulu's, concern. Note the following statement by Pak Yusuf:

"They just want the free of charge. I first glanced over them, whether they get here by motorcycle or by car. Sometimes I was hesitant to marry them in the office. Just imagine, they came here by Livina (a minibus) and the dower for the bride was 1 million. This did not make sense if they have a nikah kantor. I could not accept. Invite us to come to their home! Make nikah bedolan, and pay 600,000 for the sake of religious, worldly, and afterlife interests!"

From the above quote, Pak Yusuf tended to make relation between nikah kantor and the financial capacity of the families concerned. He thus questioned why it is hard for people to spend an extra money to make nikah bedolan whereas they will get a marriage certificate that, in his opinion, works for the worldly and religious aspects in marriage. He said "buku nikah sekali untuk seumur bidup" (a marriage certificate is once for the long life). Meanwhile, a penghulu of the KUA in the town Jember once said to me "This year (2018), we target 85\% for nikah bedolan." From both statements, it appears to me that the issue of nikah bedolan somehow resonates with an economical interest. Here is the logic. It is worth to mention that the application of multiple tariffs was an outcome of the absence of regulation concerning the incentive for pengbulu in nikah bedolan. The central government then set out the tariff of nikab bedolan, from which penghulu are legally entitled to additional incomes. Based on the regulation, from each nikah bedolan, a penghulu receives more or less Rp. 100,000 for the transportation and Rp. 150,000, or other amounts depending on the KUA category, for honorarium (jasa profesi). ${ }^{41}$ Within

41 Keputusan Direktur Jenderal Bimbingan Masyarakat Islam (the Decree of the Directorate General of Islamic guidance) No. DJ.II/748 Tahun 2014 tentang 
this sense, the fluctuating number of nikab bedolan has become a major issue amongst penghulu as it influences their incentive.

Pak Syamsu, a kepala of KUA in the town of Surabaya acknowledged that this bureaucratic reform has provided a legal certainty for the rights of penghulu in nikah bedolan on the one hand. ${ }^{42}$ However, on the other hand, it does not overcome the problem of the organisation of marriage registration in general. He referred to the low capacity of the KUA in running its everyday activity due to the limited budget allocated by the government. He argued: "The new regulation made us powerless. With the last regulation, we could still donate social or mosque activities around us. Now, the budget for KUA is very limited. We cannot do anything for our non-tenured staff and society because we do not own the money anymore." In the past, the KUA had an autonomy to manage the money received from people via modin that made it powerful institutionally. With Rp. 0 for nikah kantor and the incentive limited for penghulu from nikah bedolan, the kepala of KUA is currently challenged with the problems related to the organisation of the office. As response to this, I witnessed that some KUA encourage its penghulu not to take all the incentive, but to distribute some portion of it for the larger interest of the KUA.

Apart from this, on the basis of Migdal's state-in-society, the practice of akad dua kali has been a place where the state cannot assume its single-authoritative authority in marriage practice, and consequently, everyday agency intervenes in the making of the state practice. The practice has turned to provide what Peletz has called "the co-imbrication of law, politics, and religion". ${ }^{43}$ Akad dua kali encompasses the multiplicity of issues, ranging from state authority, religious authority, the local sense of religious validity, and penghulu's economic interest. On the one hand, there has been a local development that people strategize the multiple tariffs of marriage by concluding akad dua kali. By doing so, they

Petunjuk Teknis Pengelolaan Penerimaan Negara Bukan Pajak atas Biaya Nikah atau Rujuk di luar Kantor Urusan Agama Kecamatan (on the technical procedure of the organisation of non-tax revenue from the fees of marriage or reconciliation outside the sub-district KUA).

42 Interview with Pak Syamsu, October 2017.

43 Michael G. Peletz, "A Tale of Two Courts: Judicial Transformation and the Rise of a Corporate Islamic Governmentality in Malaysia", American Ethnologist, vol. 42, no. 1 (2015), pp. 144-60. 
manage to maintain the ideal of marriage ceremony that incorporates religious and social activities, in addition to the perception of the lack of penghuli's religious competency. The interference of traditional authority is embedded in this realm. On the other hand, this "deviation" has become a critical step stone for penghulu in the implementation of state laws on marriage at grassroot level. Penghulu, however, does not pretend to directly oppose the traditional authority. Instead, he tends to perform as the state agent, exercising his authority by the means of threat that state recognition of marriage is never possible without the possession of a marriage certificate that he signs. In addition, for penghulu himself, there is another issue pertaining to the financial incentive from nikah bedolan.

\section{F. Concluding Remarks}

On the basis of the development of a KUA office in Pasuruan society, it seems obvious that everyday life of the state body is not a compartmentalised and isolated aspect of society. In this article, Migdal's state-in-society approach has been helpful to reveal the complexities faced by penghulu and the KUA in the implementation of legal rules on marriage registration within a web of pressures from societal agencies.

I found out that the internal synergy between the KUA's officers has been the key to secure the KUA's legitimacy. First, the kepala of the KUA and the penghulu need to understand local social life, including how the local people perceive marriage ceremony, and transform it into the ground of decision. Second, non-tenured local officers also play a considerable role in communicating the state's ideas on marriage with social agencies, including modin. Third, the KUA's civil servants tend to guard the implementation of the state rules. Furthermore, in Pasuruan villages, local people regard marriage registration as a state-citizen transactional relationship. Modin serve as the key agent of brokerage. This KUA-modin-society relationship has produced the remarkable development of registered marriages and remarriages. In other words, this triangle relationship signifies the effective functioning of the state.

Nevertheless, the central Indonesian government has its own ideas on how to manage marriage registration. The central government made a regulation that has drawn a stricter boundary between nikah kantor and nikeab bedolan that it assumed effective to eradicate gratification amongst 
penghulu. In practice, this regulation has intensified the tension between religious authority and the state agency and led to the practice of akad dua kali. It seems that akad dua kali emerges as the implication of the multiple tariffs of marriage ceremony. However, it also has to do with how marriage ceremony is conceptualised locally. In everyday Muslim life, marriage ceremony entails not only religious but social activities that call for the intervention of religious leaders. At the same time, we witness the situation where penghulu are still challenged with the lack of competency about Islam. In this situation, penghulu need to redefine their position to be a legitimate agent dealing with Muslim marriages. Penghulu transformed their authority to provide state recognition of marriage into their source of power.

To conclude, in Pasuruan context, penghulu tend not to identify themselves as ulama although the identity as a religious authority remains important. Instead, penghulu identify themselves as the state agent, materialising their authority to provide state recognition of marriage into the resource of coercion. This suggests two interrelated aspects: First, they always speaks on behalf of the state. Second, marriage certificate has been an important means to defend their authority. Finally, interesting to bear in mind that modin apparently play greater roles in bridging the relationship between the state and society. Modin find themselves subject to compromise between competing legal orders that gives rise to the production of a new legal norm such as ta'kid al-nikah to make their intermediary role possible. Regardless, the fact that penghulu are not successful to persuade society to marry according to the State law in the first place suggests that they do not enjoy a solid position in society. On the other hand, with ta'kid al-nikäh, modin has created a semi-autonomous social field, which sustains customs and rules symbols internally but is also vulnerable to rules and decisions from outside the field. 


\section{BIBLIOGRAPHY}

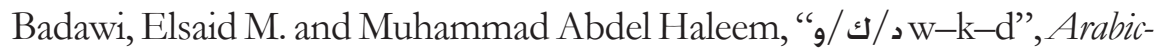
English Dictionary of Qur'anic Usage, Leiden: Brill, 2008 [https://doi. org/dx.doi.org.ezproxy.leidenuniv.nl:2048/10.1163/1875-3922_ dqu_SIM_001900].

Black, Ann, Hossein Esmaeili, and Nadirsyah Hosen, Modern Perspectives on Islamic Law, Cheltenham: Edward Elgar Publishing, 2013.

BPS Kab. Pasuruan, Kabupaten Pasuruan dalam Angka 2016, Pasuruan: BPS Kab. Pasuruan, 2017.

Bruinessen, Martin van, Tarekat Naqsyabandiyah di Indonesia, Bandung: Mizan, 1992.

Davis, D.E., "Informality and State Theory: Some Concluding Remarks", Current Sociology, vol. 65, no. 2, 2017, pp. 315-324 [https://doi. org/10.1177/0011392116657301].

Dhofier, Zamakhsyari, The Pesantren Tradition: The Role of the Kyai in the Maintenance of Traditional Islam in Java, Tempe: Arizona State University, 1999.

Hisyam, Muhamad, Caught between Three Fires: The Javanese Pangulu under the Dutch Colonial Administration, 1882-1942, Jakarta: INIS, 2001.

Kemenag, Tiga Tabun Jokowi-JK: Kemenag Pemrakarsa dan Investor Terbesar SBSN, 2017, https://kemenag.go.id/berita/read/505984/tigatahun-jokowi-jk--kemenag-pemrakarsa-dan-investor-terbesar-sbsn, accessed 7 May 2018.

Klinken, Gerry van and Joshua Barker, "Introduction: State in society in Indonesia", in State of Authority: the State in Society in Indonesia, ed. by Gerry van Klinken and Joshua Barker, Ithaca, NY: Cornell University, 2009, pp. 1-16.

Lund, Christian, "Rule and Rupture: State Formation through the Production of Property and Citizenship", Development and Change, vol. 47, no. 6, 2016, pp. 1199-228.

Migdal, Joel S., State in Society: Studying How States and Societies Transform and Constitute One Another, Cambridge: Cambridge University Press, 2001.

Mir-Hosseini, Ziba, Marriage on Trial: Islamic Family Law in Iran and Morocco, 
London and New York: I.B. Tauris, 2000.

----, "Marriage", Encyclopedia of Islam and the Muslim World, New York: Macmillan, 2004.

Nasir, Mohamad Abdun, "Islamic Law and Paradox of Domination and Resistance", Asian Journal of Social Science, vol. 44, nos. 1-2, 2016, pp. 78-103 [https://doi.org/https://doi-org.ezproxy.leidenuniv. nl:2443/10.1163/15685314-04401006].

Nichols, Joel A., "Religion, Family Law, and Competing Norms", in Negotiating State and Non-State Law: The Challenge of Global and Local Legal Pluralism, ed. by Michael A. Helfand, Cambridge: Cambridge University Press, 2015, pp. 197-214.

Nurlaelawati, Euis, Modernization, Tradition and Identity: the Kompilasi Hukum Islam and Legal Practice in the Indonesian Religious Courts, Amsterdam: Amsterdam University Press, 2010.

----, "Muslim Women in Indonesian Religious Courts: Reform, Strategies, and Pronouncement of Divorce", Islamic Law \& Society. 2013, vol. 20, no. 3, 2013, pp. 242-71 [https://doi.org/https://doi-org.ezproxy. leidenuniv.nl:2443/10.1163/15685195-0010A0003].

Peletz, Michael G., "A Tale of Two Courts: Judicial Transformation and the Rise of a Corporate Islamic Governmentality in Malaysia", American Ethnologist, vol. 42, no. 1, 2015, pp. 144-60.

Rosen, Lawrence, The Anthropology of Justice: Law as Culture in Islamic Society, Cambridge: Cambridge University Press, 1989.

Scott, Elizabeth S., "Social Norms and the Legal Regulation of Marriage", Virginia Law Review, vol. 86, no. 8, 2000, pp. 1901-70.

Weber, Max, "Politics as a Vocation", in From Max Weber: Essays in Sociology, ed. by Hans H. Gerth and C. Wright Mills, New York: Oxford University Press, 1946, pp. 77-128.

White, Adam, "Introduction. A State-in-Society Agenda", in The Everyday Life of the State: A State-In-Society Approach, ed. by Adam White, Seattle: University of Washington Press, 2013, pp. 1-12. 